\author{
https://doi.org/10.18485/dpls_pld.2020.6.ch7 \\ 316.62-057.874
}

\author{
Nataša Janković, Nenad Tomović \\ Univerzitet u Beogradu \\ Maja Aleksić \\ Institut za strane jezike u Beogradu
}

\title{
PRINCIPI I KRITERIJUMI OCENJIVANJA KAO OSNOVE VREDNOVANJA POSTIGNUĆA U OBRAZOVANJU
}

\begin{abstract}
Sažetak: Vrednovanje učeničkog postignuća u obrazovnom kontekstu treba da se zasniva na unapred definisanim principima i detaljno razrađenim kriterijumima ocenjivanja. Paralelnim istraživanjem sprovedenim u tri različite obrazovne ustanove u Beogradu ustanovili smo da završna srednjoškolska ocena nije objektivan i pouzdan pokazatelj razvijenosti kompetencija novoupisanih studenata u oblasti engleskog jezika. Sistem vrednovanja jezičkih znanja i, posebno, jezičkih veština učenika neophodno je unaprediti približavanjem standardizovanim oblicima provere postignuća, poštovanjem postojećih principa ocenjivanja, osmišljavanjem konkretnih parametara za proveru razvijenosti jezičkih kompetencija učenika i ujednačavanjem kriterijuma ocenjivanja. Tako zasnovan sistem vrednovanja bio bi i merodavniji i podsticajniji za učenike, nastavnike i obrazovni sistem u celini.
\end{abstract}

Ključne reči: principi i kriterijumi ocenjivanja, vrednovanje, jezičko znanje, jezičke veštine, jezička sposobnost.

Jedan od ključnih preduslova kvalitetnog vrednovanja učeničkog postignuća u bilo kom obrazovnom kontekstu jeste rukovođenje unapred definisanim principima i detaljno razrađenim kriterijumima ocenjivanja. Ocenjivanje je predmet dokimologije ${ }^{1}$, didaktike i metodika nastave pojedinačnih predmeta. Ocena, kao sredstvo za registrovanje uspeha učenika,

1 Naučna disciplina koja se bavi ispitivanjem, procenjivanjem i merenjem, tj. vrednovanjem vaspitno-obrazovnih postignuća učenika u školama (Potkonjak i Šimleša 1989: 144). 
ima višestruke funkcije, koje se odnose na izražavanje suda nastavnika o napredovanju i postignućima učenika (Gojkov 2003: 19). Ocenjivanje možemo da posmatramo i kao postupak kojim merimo uspeh učenika, tj. upoređujemo ga sa uspehom drugog učenika (Vilotijević 2000: 353), odnosno kao materijalizovanje $u$ vidu ocene postignutih rezultata do kojih se došlo proveravanjem i praćenjem rada učenika (Lazarević i Banđur 2001: 263).

Zakonska akta poput Pravilnika o ocenjivanju učenika u srednjem obrazovanju $i$ vaspitanju (S1. glasnik RS, br. 82/2015) određuju svrhu i principe ocenjivanja (član 2), predmet i vrste ocenjivanja (član 3), opšte kriterijume brojčanog ocenjivanja (član 5 - 11), način i postupak ocenjivanja (član 13 - 16), itd. Na osnovu ovog pravilnika:

Ocena predstavlja objektivnu i pouzdanu meru ostvarenosti propisanih ciljeva, ishoda učenja, standarda postignuća i razvijenih kompetencija, kao i napredovanja i razvoja učenika i pokazatelj je kvaliteta i efikasnosti zajedničkog rada nastavnika, učenika i škole u celini. (Član 4)

Osnovni principi na kojima se zasniva ocenjivanje, prema istom Pravilniku (član 2), su:

1)_pouzdanost: (usaglašenost ocene sa utvrđenim, javnim i preciznim kriterijumima ocenjivanja);

2)_valjanost: (ocena iskazuje efekte učenja - ostvarenost ishoda, angažovanje i napredovanje učenika);

3) raznovrsnost načina ocenjivanja: (izbor odgovarajućih i primena različitih metoda i tehnika

ocenjivanja kako bi se osigurala valjanost, pouzdanost i objektivnost ocena);

4) redovnost i blagovremenost ocenjivanja (obezbeđuje kontinuitet u informisanju učenika o

njihovoj efikasnosti u procesu učenja i efekat ocene na dalji proces učenja);

5) ocenjivanje bez diskriminacije i izdvajanja po bilo kom osnovu;

6)_uvažavanje individualnih razlika, obrazovnih potreba, uzrasta, prethodnih postignuća učenika.

Priroda nastavne građe, kao i metoda i oblika izvođenja rada $\mathrm{u}$ okviru pojedinih obrazovnih predmeta u velikoj meri se razlikuje. Zbog toga, prilikom procesa vrednovanja i ocenjivanja, pored poštovanja ovih osnovnih smernica zajedničkih za sve, nastavnici treba da se upravljaju i 
posebnim kriterijumima specifičnim za nastavu datog predmeta, koji će zadovoljiti propisane principe i garantovati objektivnost i pravednost $\mathrm{u}$ postupku ocenjivanja.

To važi i za nastavu stranog jezika, koja je bitno uslovljena složenošću jezičke građe i veština. Kao sastavni deo svakog jezika, jezičke veštine i građa neminovno se prepliću u procesu ovladavanja i služenja materijom. Upravo zbog kompleksne prirode ovog predmeta, neophodan je sveobuhvatan pristup radu, ne samo u fazama predavanja, uvežbavanja i utvrđivanja gradiva, odnosno razvijanja jezičkih kompetencija učenika, već i tokom vrednovanja njihovog rada i ocenjivanja njihovih jezičkih znanja i sposobnosti (Janković 2018: 160). Primera radi, kako ističe Mekej (McKay 2006: 215), samo kod ocenjivanja veštine govora, nastavnik treba da ima na umu da li je učenicima pružena mogućnost da zaista pokažu koliko znaju u vidu različitih oblika interakcije sa drugima, da li je zadatak adekvatne težine za dati nivo njihovog poznavanja jezika, kako najbolje da proceni njihovo poznavanje gramatike, bogatstvo rečnika i izgovor prilikom usmenog odgovora. Osim toga, prema Braunu (Brown 2004: 281), ne treba zaboraviti da ocena, mada u obliku sasvim proste brojke ${ }^{2}$, ne odražava samo napore učenika u ovladavanju toliko složenom materijom i njegova zalaganja tokom cele godine, već ujedno predstavlja i elementarni faktor njegovog samopouzdanja tokom školovanja. Brojna iskustva iz domaće prakse upućuju na zaključak da se upravo taj aspekt ocenjivanja u domaćoj sredini često zapostavlja ili, pak, sasvim proizvoljno sagledava, bez oslanjanja na jasne kriterijume procene. Primenljivost školskog znanja u realnim životnim situacijama zavisiće od kvaliteta naučenog. Prema Fulčeru (Fulcher 2017: 180), kvalitet datog jezičkog uzorka omogućava nam da procenimo nečiju jezičku sposobnost, jer se uzorak govornog ili pisanog jezika prilikom testiranja ocenjuje sa aspekta određene komunikativne svrhe.

Razmatrajući proces vrednovanja na širem planu, Anđelo i Krosova (Angelo and Cross 1988: 3) tvrde da sve obrazovne ustanove, ma koliko ih bilo na nekom području, imaju jedan isti zajednički cilj, a to je da učenicima pomognu da uče brže i efikasnije nego što bi to mogli samostalno. U tom smislu, ocenjivanje nastavnicima pomaže da steknu uvid u to šta, kako i koliko su njihovi učenici savladali, kako bi i sami svoj rad preusmerili upravo tako da im omoguće brže i efikasnije učenje. Stoga samovrednovanje, kako učenika, tako i nastavnika, čini veoma važan

${ }^{2}$ Prema izvornom tekstu, karakteristično za anglosaksonski sistem ocenjivanja, navodi se slovna ocena. 
segment sveukupnog procesa vrednovanja. Uprkos brojnim prednostima samovrednovanja, njegov ključni nedostatak može biti u tome što je najčešće neformalno, pa samim tim deluje i manje obavezujuće za učenike i nastavnike, za razliku od klasičnog merenja učeničkih postignuća. Uz to, poznato je da i tradicionalno školsko ocenjivanje ima svojih mana. Rezultati ovog istraživanja pokazaće kakva je situacija sa ocenjivanjem u nastavi engleskog jezika.

\section{Cilj istraživanja}

Nastojeći da ustanovimo koliko je ocena objektivna i pouzdana kao sredstvo kojim se opisuje razvijenost učeničkih kompetencija u oblasti engleskog jezika i ostvarenost propisanih ciljeva školske nastave engleskog jezika u trenutku kada srednjoškolci prelaze na univerzitetski nivo obrazovanja, sproveli smo paralelno istraživanje u tri različite obrazovne ustanove - na Učiteljskom i Filološkom fakultetu Univerziteta u Beogradu i na Institutu za strane jezike u Beogradu. Podsticaj za ovakvu komparativnu studiju predstavlja isto istraživanje prethodno sprovedeno samo na Učiteljskom fakultetu u Beogradu. Ono nas je dovelo do zaključka da završna srednjoškolska ocena iz engleskog jezika nije realan pokazatelj znanja novoupisanih studenata, da nisu jasni i ujednačeni kriterijumi ocenjivanja kod učenika naših škola i da je neophodno sistem vrednovanja njihovih postignuća zasnivati na podsticajnim i standardizovanim oblicima provere kako bismo im blagovremeno omogućili da razvijaju svoju jezičku sposobnost (Janković 2017: 51). Ovakve nalaze želeli smo dodatno da proverimo na većem i raznovrsnijem uzorku ispitanika.

\section{Instrumenti istaživanja}

Istraživanje je zasnovano na primeni dva instrumenta. Prvi je anketa o kvalitetu nastave engleskog jezika i ocenjivanja u završnom razredu srednjeg obrazovanja; drugi je test znanja koji je na početku šk. 2017/18. god. primenjen u funkciji dijagnostičkog testa. S obzirom na to da ključnu temu ovog rada predstavljaju pricipi i kriterijumi ocenjivanja, fokusiraćemo se na jedan deo nalaza, tj. na uporedni pregled školskih ocena $\mathrm{i}$ rezultata pomenutog inicijalnog testiranja, dok ćemo detaljno segmentiranu analizu kvaliteta srednjoškolske nastave engleskog jezika na osnovu ankete dati u drugom, zasebnom radu. Sledi opšti prikaz primenjenih istaživačkih instrumenata. 
Anketa se sastoji od dva dela:

a) uvodni deo, putem koga smo ustanovili:

- sastar populacije,

- tip škola iz kojih ispitanici dolaze,

- njihovu ocenu iz engleskog jezika iz završnog razreda gimnazije/ srednje škole,

- način i period učenja engleskog jezika;

b) glavni deo, koji sadrži deset pitanja, od kojih četiri uključuju i niz potpitanja, putem kojih smo ispitali kvalitet nastave u smislu:

- učestalosti korišćenja engleskog jezika u komunikaciji na času,

- raznovrsnosti aktivnosti usmerenih ka ovladavanju jezičkom građom i jezičkim veštinama,

- raznovrsnosti aktivnosti prilikom ocenjivanja jezičkih znanja i jezičke sposobnosti učenika,

- ličnih sklonosti i iskustva u korišćenju engleskog jezika.

Posebno važno bilo nam je da ustanovimo:

- kojom školskom ocenom bi učesnici ankete objektivno sami sebe ocenili iz engleskog jezika na kraju srednjeg obrazovanja i

- koliko su lično zadovoljni nastavom engleskog jezika tokom srednje škole.

Dali smo im priliku i da iskažu probleme sa kojima su se suočavali u nastavi, kao i mišljenje o tome šta bi trebalo promeniti u školskoj nastavi engleskog jezika.

\section{$>$ Inicijalni test}

Shodno različitom karakteru prijemnih ispita, odnosno provera znanja u oblasti engleskog jezika, za razliku od ankete, inicijalni test primenjen u tri ustanove nije bio identičan, što predstavlja otežavajući faktor u izvođenju zbirnih rezultata. Uprkos tome, svaka od tri ustanove primenila je njoj svojstvene i već ustaljene standardizovane metode provere znanja, putem kojih na početku školske godine utvrđuje nivo jezičkih znanja i sposobnosti novoupisanih polaznika.

Na Filološkom fakultetu, za potrebe istraživanja iskorišćeni su rezultati testa znanja i sposobnosti primenjenog u okviru prijemnog ispita za pomenutu školsku godinu, pri čemu je očekivani nivo znanja pretežno orijentisan ka nivou B2+ prema ZEO (Tomović, Aralica, Rasulić 2016: 108). Prijemni ispit za anglistiku sastoji se iz više delova koji testiraju: a) 
gramatiku i vokabular u kontekstu, b) razumevanje pročitanog teksta, c) razumevanje teksta koji se sluša i d) pisanje (u formi eseja). Prilikom izrade testa vodi se računa o važećem školskom nastavnom planu i programu.

Na Učiteljskom fakultetu, kao i kod prvobitnog istraživanja, primenjen je Quick Placement Test, zasnovan na međunarodnim kriterijumima ocenjivanja koje propisuju University of Cambridge ESOL Examinations, u očekivanom rasponu nivoa A1 - C2. Podeljeni u dva dela testa (od kojih drugi rade kandidati koji dostignu zadovoljavajući broj poena $u$ prvom delu), zadaci proveravaju primenu vokabulara i gramatike u kontekstu, uključujući i razumevanje pročitanog teksta.

* Na Institutu za strane jezike primenjen je interni test za proveru nivoa znanja (Placement Test) usklađen sa preporukama ZEO, a u rasponu nivoa A2 - C2. Budući da vanškolske institucije za učenje stranih jezika funkcionišu istovremeno i kao privredna društva i kao obrazovne ustanove, kriterijumi za pohađanje nastave nisu identični onima na Filološkom fakultetu Univerziteta u Beogradu. Učenici rade dijagnostički test koji pruža okvirni uvid u njihovo pasivno znanje u najširem smislu, a prilikom određivanja nivoa koji će pohađati presudan je strukturirani intervju na osnovu koga se procenjuje trenutni nivo njihove aktivne upotrebe jezika.

$\mathrm{S}$ obzirom na to da $\mathrm{u}$ istraživanju nivo postignuća (A1 - C2) prema ZEO nije utvrđen istovetnim instrumentom, baziraćemo se na procentualno iskazanim rezultatima testa u odnosu na ukupnu populaciju svake od tri ustanove i u odnosu na ključne rezultate dobijene putem ankete.

\section{Uzorak istraživanja/populacija}

Populaciju uključenu u istraživanje činile su tri grupe ispitanika:

- 204 studenta (anketa), tj. 209 studenata (test znanja) prve godine Učiteljskog fakulteta, od kojih većina anketiranih (70\%) dolazi iz srednjih stručnih škola, sa uobičajenim fondom od 2 časa engleskog jezika nedeljno;

- 107 studenata (anketa), tj. 135 studenata (prijemni ispit) prve godine Filološkog fakulteta, od kojih većina anketiranih (58.88\%) dolazi iz gimnazija društvenog smera, sa uobičajenim fondom od 4 časa engleskog jezika nedeljno (39.25\%), i filoloških odeljenja, sa fondom od 5 časova nedeljno (19.63\%);

- 33 novoupisanih polaznika kurseva engleskog jezika Instituta za strane jezike, starosti 18-65 godina, od kojih je većina (61\%), završila 
četvorogodišnju srednju školu, sa fondom od pretežno 2 časa engleskog jezika nedeljno. ${ }^{3}$

Tip škole, kao i nedeljni, tj. ukupni fond časova nastave engleskog jezika bitno uslovljavaju kvalitet nastave i način vrednovanja učeničkih postignuća, kao i dostignuti nivo jezičke kompetencije, a samim tim i rezultate našeg testiranja.

\section{Uporedni pregled rezultata istraživanja u tri ustanove:}

I Anketa - izdvajamo tri ključna podatka vezana za temu ovog rada: a) školsku ocenu iz engleskog jezika (iz uvodnog dela ankete), b) ocenu koju bi ispitanici dali sami sebi i c) ocenu koju bi dali srednjoškolskoj nastavi engleskog jezika (pitanja br. 7 i 8 glavnog dela ankete).

Tabela 1 Studenti Učiteljskog fakulteta o školskoj oceni i nastavi engleskog jezika

\begin{tabular}{|c|c|c|c|c|c|}
\hline \multirow{2}{*}{$\begin{array}{l}\text { Koju ste ocenu imali u } \\
\text { završnom razredu gimnazije/ } \\
\text { srednje škole? }\end{array}$} & 1 & 2 & 3 & 4 & 5 \\
\hline & - & $\begin{array}{c}(17) \\
8.33 \%\end{array}$ & $\begin{array}{c}(39) \\
19.12 \%\end{array}$ & $\begin{array}{c}(44) \\
21.57 \%\end{array}$ & $\begin{array}{c}(104) \\
50.98 \%\end{array}$ \\
\hline \multirow{2}{*}{$\begin{array}{l}\text { Kojom ocenom biste Vi ocenili } \\
\text { svoje znanje engleskog u } \\
\text { završnoj godini gimnazije/ } \\
\text { srednje škole? }\end{array}$} & 1 & 2 & 3 & 4 & 5 \\
\hline & $\begin{array}{c}(2) \\
0.98 \%\end{array}$ & $\begin{array}{c}(30) \\
14.70 \%\end{array}$ & $\begin{array}{c}(80) \\
39.22 \%\end{array}$ & $\begin{array}{c}(65) \\
\mathbf{3 1 . 8 7 \%}\end{array}$ & $\begin{array}{c}(27) \\
13.23 \%\end{array}$ \\
\hline \multirow{2}{*}{$\begin{array}{l}\text { Koliko ste na skali od } 1 \text { do } 5 \\
\text { zadovoljni nastavom engleskog } \\
\text { jezika u toku srednje škole/ } \\
\text { gimnazije? } \\
\text { (Zaokružite odgov. broj.) }\end{array}$} & 1 & 2 & 3 & 4 & 5 \\
\hline & $\begin{array}{c}(13) \\
6.37 \%\end{array}$ & $\begin{array}{c}(37) \\
18.14 \%\end{array}$ & $\begin{array}{c}(68) \\
33.33 \%\end{array}$ & $\begin{array}{c}(48) \\
23.53 \%\end{array}$ & $\begin{array}{c}(38) \\
18.63 \%\end{array}$ \\
\hline
\end{tabular}

Tabela 1, kao konkretan indikator neobjektivnosti ocena, upućuje i na zaključak o visokom stepenu samokritičnosti studenata prve godine Učiteljskog fakulteta, koji ni izbliza sebi ne bi dali onoliko petica koliko ih ima u njihovim školskim svedočanstvima. Njihova procena kvaliteta nastave takođe se pretežno kreće na nivou ocene dobar (3), što znači da su imali veća očekivanja od školske nastave engleskog jezika. Važan podatak je da dve trećine čine bivši učenici srednjih stručnih škola i da se njihova nastava svodila na fond od dva časa engleskog jezika nedeljno.

\footnotetext{
${ }^{3}$ U tabelarnim i tekstualnim prikazima, tri ustanove biće predstavljene odgovarajućim akronimima: UF, FF i ISJ.
} 
Tabela 2 Studenti Filološkog fakulteta o školskoj oceni i nastavi engleskog jezika

\begin{tabular}{|c|c|c|c|c|c|c|}
\hline \multirow{2}{*}{$\begin{array}{l}\text { Koju ste ocenu imali } \\
\text { u završnom razredu } \\
\text { gimnazije/srednje } \\
\text { škole? }\end{array}$} & ne zna & 1 & 2 & 3 & 4 & 5 \\
\hline & $\begin{array}{c}(1) \\
0.93 \%\end{array}$ & - & - & $\begin{array}{c}(1) \\
0.93 \%\end{array}$ & $\begin{array}{c}(18) \\
16.82 \%\end{array}$ & $\begin{array}{c}(87) \\
\mathbf{8 1 . 3 0 \%}\end{array}$ \\
\hline \multirow{2}{*}{\multicolumn{2}{|c|}{$\begin{array}{l}\text { Kojom ocenom biste Vi ocenili } \\
\text { svoje znanje engleskog u } \\
\text { završnoj godini gimnazije/ } \\
\text { srednje škole? }\end{array}$}} & 1 & 2 & 3 & 4 & 5 \\
\hline & & - & $\begin{array}{c}(1) \\
\mathbf{0 . 9 3} \%\end{array}$ & $\begin{array}{c}(3) \\
\mathbf{2 . 8 0 \%}\end{array}$ & $\begin{array}{c}(19) \\
17.76 \%\end{array}$ & $\begin{array}{c}(84) \\
\mathbf{7 8 . 5 0} \%\end{array}$ \\
\hline \multirow{2}{*}{\multicolumn{2}{|c|}{$\begin{array}{l}\text { Koliko ste na skali od } 1 \text { do } 5 \\
\text { zadovoljni nastavom engleskog } \\
\text { jezika u toku srednje škole/ } \\
\text { gimnazije? } \\
\text { (Zaokružite odgov. broj.) }\end{array}$}} & 1 & 2 & 3 & 4 & 5 \\
\hline & & $\begin{array}{c}(5) \\
4.67 \%\end{array}$ & $\begin{array}{c}(21) \\
\mathbf{1 9 . 6 3 \%}\end{array}$ & $\begin{array}{c}(23) \\
\mathbf{2 1 . 4 9 \%}\end{array}$ & $\begin{array}{c}(21) \\
\mathbf{1 9 . 6 3 \%}\end{array}$ & $\begin{array}{c}(37) \\
\mathbf{3 4 . 5 8 \%}\end{array}$ \\
\hline
\end{tabular}

Iz Tabele 2 evidentna je veća lična orijentisanost ispitanika ka karijeri u oblasti anglistike (što su potvdili i odgovorima na anketno pitanje br. 6, o njima bitnim vanškolskim sadržajima vezanim za upotrebu engleskog jezika), tako da se i njihove lične procene u velikoj meri podudaraju sa ocenama koje su im dali nastavnici. Ipak, tek blizu polovine njih jednako visoko bi vrednovalo kvalitet školske nastave engleskog jezika, iako je većinski reč o bivšim učenicima gimnazija, sa fondom od 4-5 časova engleskog nedeljno.

Tabela 3 Polaznici Instituta za strane jezike o školskoj oceni i nastavi engleskog jezika

\begin{tabular}{|c|c|c|c|c|c|c|}
\hline \multirow{2}{*}{$\begin{array}{l}\text { Koju ste ocenu imali } \\
\text { u završnom razredu } \\
\text { gimnazije/srednje škole? }\end{array}$} & ne zna & 1 & 2 & 3 & 4 & 5 \\
\hline & $\begin{array}{l}2) \\
6 \% \\
\end{array}$ & - & $\begin{array}{l}(1) \\
\mathbf{3 \%} \\
\end{array}$ & $\begin{array}{c}(4) \\
12 \%\end{array}$ & $\begin{array}{c}(8) \\
24 \%\end{array}$ & $\begin{array}{r}(18) \\
\mathbf{5 5 \%}\end{array}$ \\
\hline \multirow{2}{*}{\multicolumn{2}{|c|}{$\begin{array}{l}\text { Kojom ocenom biste Vi ocenili } \\
\text { svoje znanje engleskog u završnoj } \\
\text { godini gimnazije/srednje škole? }\end{array}$}} & 1 & 2 & 3 & 4 & 5 \\
\hline & & - & $\begin{array}{c}(6) \\
18 \%\end{array}$ & $\begin{array}{l}(10) \\
\mathbf{3 0 \%}\end{array}$ & $\begin{array}{l}(11) \\
\mathbf{3 3 \%}\end{array}$ & $\begin{array}{c}(6) \\
18 \%\end{array}$ \\
\hline \multirow{2}{*}{\multicolumn{2}{|c|}{$\begin{array}{l}\text { Koliko ste na skali od } 1 \text { do } 5 \\
\text { zadovoljni nastavom engleskog } \\
\text { jezika u toku srednje škole/ } \\
\text { gimnazije? } \\
\text { (Zaokružite odgov. broj.) }\end{array}$}} & 1 & 2 & 3 & 4 & 5 \\
\hline & & $\begin{array}{c}(8) \\
\mathbf{2 4 \%}\end{array}$ & $\begin{array}{l}(10) \\
\mathbf{3 0 \%}\end{array}$ & $\begin{array}{c}(7) \\
21 \%\end{array}$ & $\begin{array}{c}(6) \\
18 \%\end{array}$ & $\begin{array}{l}(2) \\
6 \%\end{array}$ \\
\hline
\end{tabular}


Tabela 3 navodi na zaključke da ni ova heterogena populacija ispitanika (takođe većinom iz srednjih škola, manjim delom iz gimnazija) nema visoko mišljenje o sopstvenom poznavanju engleskog u odnosu na dobijene školske ocene, niti o kvalitetu školske nastave ovog jezika.

Poređenje ocena između tri tabele, kao i unutar svake tabele pojedinačno, ukazuje na neujednačene, a delom i neobjektivne kriterijume ocenjivanja kod različitih populacija učenika. Takođe je očigledno da se veći fond časova pozitivno odražava na kvalitet znanja učenika i njihovo samopouzdanje po pitanju dobijenih ocena. Ostaje pitanje da li su nastavnici škola sa manjim fondom časova najviše ocene zasnivali možda pre na zalaganju učenika nego na njihovom znanju ili je reč o ozbiljnom odsustvu pravih kriterijuma vrednovanja.

Po pitanju ocenjivanja, u svojim dopisanim komentarima mnogi učesnici istraživanja dodatno insistiraju da se pažnja posveti svim učenicima podjednako, a ne samo onima ,koji dobro znaju”. Među primedbama ispitanika iz sve tri ustanove ubedljivo preovladava potreba za pojačanim vežbama konverzacije, ali i za češćim vežbama pisanja tekstova poput sastava i pisama.

Sledeći problem je neravnoteža između zastupljenosti jezičkih veština u samoj nastavi, koja se lako može identifikovati na osnovu ankete, a značajno doprinosi i nerealnom ocenjivanju. Naime, rezultati ankete nedvosmisleno pokazuju da veliki broj nastavnika ne uzima ravnopravno sve jezičke veštine u obzir u procesu vrednovanja, a činjenica da su gramatika i prevođenje $u$ fokusu prilikom ocenjivanja deluje poražavajuće jer upućuje na zaključak da je odavno prevaziđeni gramatičko-prevodni metod i dalje veoma zastupljen. Prema iskazima anketiranih u pitanju br. 5, o elementima koji su njihovim nastavnicima u školi bili najvažniji kod ocenjivanja, apsolutno prvo mesto drži gramatika (UF - 45,58\% ispitanika, FF $-69,15 \%$ ispitanika, ISJ - $60,60 \%$ ispitanika). Drugo mesto po značaju za njihove nastavnike pripalo je čitanju i prevodu kod učenika pristiglih uglavnom iz srednjih/stručnih škola (UF - 39,21\%, ISJ - 27,27\%), dok je pretežno kod gimnazijalaca (FF - 23,36\%) ovaj pristup ocenjivanju četvrti po značaju. Kod ovog dela populacije vokabular dobija drugo mesto (FF - 38,31\%), a kod ostalih ispitanika treće (UF - 34,80\% i ISJ - 24,24\%). Komunikacija sa nastavnikom kod ispitanika UF i ISJ zauzela je tek četvrto mesto po značaju, a samo kod grupe sa FF treće. Sledeća najvažnija stavka je u većini slučajeva prepričavanje teksta lekcije. Zanimljiv je podatak da je izgovor ocenjen kao srednje važan kod učesnika sa UF i ISJ, 
dok je za školske nastavnike najvećeg broja ispitanika sa FF (29,90\%), izgovor bio nevažan. Ubedljivo najlošiju poziciju kod čitave ispitane populacije drži komunikacija između samih učenika, koja je kod svih većinski kategorisana kao nevažan faktor kod ocenjivanja (UF - 33,82\%; FF - 36,44\%; ISJ - 45,45\%). To jasno oslikava jedan od najvećih uzročnika ograničene komunikativne sposobnosti naših maturanata, što u velikom broju slučajeva postaje evidentno sa njihovim prelaskom na univerzitetski nivo obrazovanja. Upravo ovo zapažanje bilo je osnovni podsticaj za prvobitno, kao i ovo prošireno istraživanje.

II Inicijalni test - U ovom delu rada dajemo uporedni pregled školske ocene i rezultata ulaznog testiranja. S jedne strane, u skladu sa Pravilnicima o ocenjivanju učenika u školama, znamo da ocene nisu samo odraz pokazanog znanja u okviru predmeta, već i zalaganja učenika, redovnosti izvršavanja obaveza, njihovih subjektivnih mogućnosti i drugih faktora. Osim toga, poznato je da se nastavnici služe i različitim skalama vrednovanja prilikom testiranja (neki dodeljuju po $20 \%$ za svaku ocenu, drugi očekuju 50\% ili $60 \%$ tačnih odgovora za prelaznu ocenu itd.), što dodatno zavisi i od uzrasta učenika, oblasti jezika koja se vrednuje, kao i vrste i sadržaja testa. S druge strane, činjenica je da dijagnostički, klasifikacioni i drugi standardizovani testovi daju objektivniju sliku o znanju kandidata, iskazanu u vidu brojčane vrednosti prema unapred definisanoj skali vrednovanja.

To i u slučaju našeg rada otežava poređenje školske ocene i rezultata testiranja. Osim toga, prijemni ispit Filološkog fakulteta svakako je sadržajniji od inicijalnih testova druge dve ustanove. Ipak, rezultati dobijeni na osnovu ovih različitih standardizovanih skala vrednovanja dovoljno govore o nivou postignuća ispitanika sve tri ustanove u odnosu na očekivanu razvijenost njihovih jezičkih znanja i veština na kraju srednjeg obrazovanja, naročito sa aspekta (ne)adekvatnog fonda časova engleskog jezika za razvoj učeničkih jezičkih kompetencija.

Pošto testiranje i anketiranje učesnika nije obavljeno u istom danu, broj ispitanika Učiteljskog i Filološkog fakulteta donekle je veći u drugoj fazi istraživanja. Tabele 4, 5 i 6 prikazuju konačne rezultate testiranja u odnosu na standardizovane skale vrednovanja svake institucije. 
Tabela 4 Rezultati inicijalnog testa - Učiteljski fakultet:

\begin{tabular}{|c|c|c|c|c|c|}
\hline \multicolumn{4}{|c|}{$\begin{array}{c}\text { Skala bodovanja na inicijalnom testu } \\
(\text { sa } 25+\text { poena na T1, student radi i T2) }\end{array}$} & \multicolumn{2}{c|}{$\begin{array}{c}\text { Rezultati testiranja } \\
(209 \text { ispitanika) }\end{array}$} \\
\hline $\begin{array}{c}\text { CEFR } \\
\text { (ALTE) }\end{array}$ & $\begin{array}{c}\text { Test } 1 \\
0-40 \\
\text { poena }\end{array}$ & $\begin{array}{c}\text { Test1+Test2 } \\
0-60 \\
\text { poena }\end{array}$ & $\begin{array}{c}\text { Postignuće } \\
\text { u \% }\end{array}$ & $\begin{array}{c}\text { Broj studenata na } \\
\text { datom nivou } \\
\text { postignuća }\end{array}$ & $\begin{array}{c}\text { Broj } \\
\text { studenata } \\
\text { u \% }\end{array}$ \\
\hline A1 & $0-15$ & $0-17$ & $0-29 \%$ & 34 & $\mathbf{1 6 . 2 7 \%}$ \\
\hline A2 & $16-23$ & $18-29$ & $30-49 \%$ & 79 & $\mathbf{3 7 . 8 0 \%}$ \\
\hline B1 & $24-30$ & $30-39$ & $50-65 \%$ & 58 & $\mathbf{2 7 . 7 5 \%}$ \\
\hline B2 & $31-40$ & $40-47$ & $66-78 \%$ & 29 & $\mathbf{1 3 . 8 8 \%}$ \\
\hline C1 & & $48-54$ & $80-90 \%$ & 5 & $\mathbf{2 . 3 9 \%}$ \\
\hline C2 & & $54-60$ & $90-100 \%$ & 4 & $\mathbf{1 . 9 1 \%}$ \\
\hline
\end{tabular}

Prema ovim rezultatima, većina tek upisanih studenata Učiteljskog fakulteta dolazi iz srednjih škola sa znanjem enlgeskog jezika na nivou A2, a zatim i B1. Nije zanemarljiv procenat onih sa znanjem na nivou A1, ali protivtežu njima čine i svršeni maturanti sa znanjem na nivou B2 i C.

Tabela 5 Rezultati inicijalnog testa - Filološki fakultet:

\begin{tabular}{|c|c|c|c|c|}
\hline \multicolumn{2}{|c|}{$\begin{array}{c}\text { Skala bodovanja na prijemnom ispitu } \\
\text { (min. 24 / max. 40 poena) }\end{array}$} & \multicolumn{2}{c|}{$\begin{array}{c}\text { Rezultati testiranja } \\
\text { (135 ispitanika) }\end{array}$} \\
\hline \multirow{2}{*}{ CEFR } & $\begin{array}{c}\text { Broj poena } \\
\text { na testu }\end{array}$ & $\begin{array}{c}\text { Postignuće } \\
\mathrm{u} \%\end{array}$ & $\begin{array}{c}\text { Broj studenata } \\
\text { na datom nivou } \\
\text { postignuća }\end{array}$ & $\begin{array}{c}\text { Broj studenata } \\
\mathrm{u} \%\end{array}$ \\
\hline A1 - B1 & $<24$ boda & $<60 \%$ & - & - \\
\hline \multirow{3}{*}{$\begin{array}{c}\text { B2 - B2+ } \\
\text { (C1) }\end{array}$} & $24-28 \mathrm{p}$. & $60-70 \%$ & 19 & $\mathbf{1 4 . 0 7 \%}$ \\
\cline { 2 - 5 } RC LC & $29-32 \mathrm{p}$. & $71-80 \%$ & 61 & $\mathbf{4 5 . 1 9 \%}$ \\
\cline { 2 - 5 } & $33-36 \mathrm{p}$. & $81-90 \%$ & 44 & $\mathbf{3 2 . 5 9 \%}$ \\
\hline
\end{tabular}

Očekivano, novoupisani studenti katedre za anglistiku Filološkog fakulteta postižu rezultate u skladu sa opredeljenjem za buduću profesiju i većinom pokazuju znanje na nivoima B2-C1, ka kojima je orijentisana i težina samog prijemnog ispita. 
Tabela 6 Rezultati inicijalnog testa - Institut za strane jezike:

\begin{tabular}{|c|c|c|c|c|}
\hline \multicolumn{2}{|c|}{ Skala bodovanja na prijemnom ispitu } & \multicolumn{2}{c|}{ Rezultati testiranja (33 ispitanika) } \\
\hline CEFR & $\begin{array}{c}\text { Broj poena } \\
\text { na testu }\end{array}$ & $\begin{array}{c}\text { Postignuće } \\
\mathrm{u} \%\end{array}$ & $\begin{array}{c}\text { Broj polaznika } \\
\text { na datom nivou } \\
\text { postignuća }\end{array}$ & $\begin{array}{c}\text { Broj studenata } \\
\mathrm{u} \%\end{array}$ \\
\hline A2 & $18-26$ & $30-44 \%$ & 9 & $\mathbf{2 7 \%}$ \\
\hline B1 & $27-36$ & $45-60 \%$ & 15 & $\mathbf{4 5 \%}$ \\
\hline B2 & $37-45$ & $61-75 \%$ & 6 & $\mathbf{1 8 \%}$ \\
\hline C1 & $46-54$ & $76-90 \%$ & 2 & $\mathbf{6 \%}$ \\
\hline C2 & $55-60$ & $91-100 \%$ & 1 & $\mathbf{3 \%}$ \\
\hline
\end{tabular}

Većina ove populacije različitih uzrasta pokazala je znanje na nivou B1, mada je priličan postotak kandidata na nivou A2 i jednak broj onih koji zbirno dostižu nivoe B2 i C.

Radi preciznijeg poređenja školske ocene i rezultata inicijalnog testa, treba naglasiti da Pravilnik o opštim standardima postignuća za kraj opšteg srednjeg obrazovanja (Sl. glasnik RS, br. 117/2013) prepoznaje osnovni, srednji i napredni nivo postignuća, što prema Zajedničkom evropskom okviru za jezike odgovara nivoima A2, B1 i B2. Početni i viši nivoi nisu navedeni u pomenutom pravilniku za naše srednje škole. Očekivano je da se prilikom testiranja pojave ispitanici i na tim nivoima postignuća, ali svakako ne u velikom broju. Znajući da se za kraj srednjeg obrazovanja kod većine učenika očekuje dostizanje srednjeg nivoa (B1) tabele otkrivaju poražavajući broj ispitanika koji su nakon srednje škole ostali na osnovnom nivou (UF - 37,80\% i ISJ - 27\%), pa čak i početnom nivou (UF - 16,27\%) postignuća.

Uporedni pregled rezultata testiranja i srednjoškolske ocene uglavnom pokazuje obrnuti trend u skaliranju uspeha, odnosno opadanje broja kandidata od nižih ka višim nivoima postignuća, dok je kod školske ocene situacija upravo suprotna i odražava porast broja učenika od nižih ka višim ocenama. Situacija je donekle ujednačena samo u slučaju Filološkog fakulteta, što je razumljivo jer su ovi kandidati unapred orijentisani ka napredovanju u jeziku, dolaze iz škola sa najvećim fondom časova i najnižom ocenom dobar (3). Kod Učiteljskog fakulteta i Instituta za strane jezi-

4 U domaćem obrazovnom sistemu nivo A1 očekuje se na kraju prvog ciklusa osnovnog obrazovanja, nivo A2 na kraju osnovne škole, nivo B1 na kraju srednjeg obrazovanja. 
ke, slika je drugačija i odražava nelogičnosti u primenjenim kriterijumima ocenjivanja u odnosu na rezultate dijagnostičkog testa, što se može videti u donjem prikazu.

Tabela 7 - Odnos postignuća na testu i školske ocene kod tri grupe ispitanika

\begin{tabular}{|c|c|c|c|c|c|c|c|c|c|c|c|}
\hline & $\begin{array}{l}\text { UF } \\
\text { test }\end{array}$ & $\begin{array}{c}\text { SŠ } \\
\text { ocena }\end{array}$ & & & $\begin{array}{l}\text { FF } \\
\text { test }\end{array}$ & $\begin{array}{c}\text { SŠ } \\
\text { ocena }\end{array}$ & & & $\begin{array}{l}\text { ISJ } \\
\text { test }\end{array}$ & $\begin{array}{c}\text { SŠ } \\
\text { ocena }\end{array}$ & \\
\hline A1 & $16.27 \%$ & --- & & & --- & --- & & & & --- & \\
\hline \multirow[t]{3}{*}{ A2 } & $37.80 \%$ & $8.33 \%$ & 2 & & - & $\ldots$ & & A2 & $27 \%$ & $3 \%$ & 2 \\
\hline & $27.75 \%$ & $19.12 \%$ & & B2 & $14.07 \%$ & $0.93 \%$ & 3 & & $45 \%$ & $12 \%$ & \\
\hline & $13.88 \%$ & $21.57 \%$ & & & $45.19 \%$ & $16.82 \%$ & & & $18 \%$ & $24 \%$ & \\
\hline \multirow[t]{2}{*}{$\mathrm{C1}^{+}$} & $2.39 \%$ & $50.98 \%$ & 5 & $\mathrm{C1}^{+}$ & $32.59 \%$ & $81.30 \%$ & 5 & & $6 \%$ & $55 \%$ & \\
\hline & $1.91 \%$ & & & & $8.15 \%$ & & & $\mathrm{C1}^{+}$ & $3 \%$ & & 5 \\
\hline
\end{tabular}

Kao što se vidi iz ankete i rezultata koje su studenti postigli, kriterijumi ocenjivanja se dosta razlikuju od jedne do druge školske ustanove, tj. od nastavnika do nastavnika. To se negativno odražava na kvalitet znanja učenika, a i na njihovo samopouzdanje u stremljenju ka višim nivoima postignuća u državnom obrazovnom sistemu. Ocene zasnovane na tako neujednačenim kriterijumima očigledno u velikom broju slučajeva nisu pravo merilo uspeha i ne daju objektivnu sliku o poznavanju materije ni samim učenicima ni obrazovnim ustanovama.

\section{Zaključna razmatranja i predlog korektivnih mera}

Rezultati ovog istraživanja pokazali su da se u mnogim školama iz kojih su došli ispitanici ne poštuju propisani principi pouzdanosti, valjanosti i raznovrsnosti načina ocenjivanja, kao i to da se u njima često ne primenjuju jasni, ujednačeni, a ni objektivni kriterijumi ocenjivanja. Očigledan dokaz toga je razlika između nivoa postignuća i školskih ocena tri grupe ispitanika. Testiranje pokazuje da je prevelik broj učenika na kraju srednje škole ostao na osnovnom, pa čak i početnom nivou poznavanja engleskog jezika, dok odgovori na pitanja iz ankete odražavaju zapostavljenost jezičkih veština i razvoja komunikativne kompetencije učenika u odnosu na gramatiku i prevod.

U vreme pisanja ovog rada, osim opštih standarda postignuća, ne postoje konkretnije smernice koje bi nastavnicima pomogle da se rukovode prilikom provera znanja i ocenjivanja učenika na polju jezičkih veština, naročito produktivnih (veština govora i pisanja), tj. integrisanih 
jezičkih znanja i veština. Mada ni sama anketa nije mogla dati odgovore o tome kako se ove veštine ocenjuju, već samo o tome koliko se uzimaju u obzir, može se videti da rad na njima nije adekvatan. Stoga je za njih potrebno ponuditi konkretne parametre i kriterijume ocenjivanja i obezbediti deskriptore po uzoru na već postojeće standardizovane ispite, kao npr. za IELTS, za koji postoje tzv. writing/speaking band descriptors, a koji daju mogućnost za objektivnije ocenjivanje jezičkih veština i nivoa poznavanja jezika.

Rekli smo da su u školskom sistemu vrednovanja prisutni različiti pristupi ocenjivanju u zavisnosti od oblasti jezika koja se testira, načina testiranja i skala bodovanja koje nastavnici primenjuju. Da bi sistem ocenjivanja bio ujednačeniji i objektivniji, neophodno je sistem vrednovanja zasnivati na podsticajnim i standardizovanim oblicima provere, kako bi učenicima ocena služila ne samo kao pouzdan odraz dotadašnjih zalaganja, već i kao dragocena smernica za dalji napredak. Rezultati studentskog postignuća dobijeni ovim istraživanjem na akademskom nivou mogu se smatrati pouzdanijim od školskih ocena ispitanika upravo zato što su zasnovani na standardizovanim načinima provere znanja i skalama vrednovanja. Problem je što se u školama kontinuirano ocenjivanje, koje čini osnovu za završnu ocenu, ne vrši na osnovu standarda, već na osnovu subjektivnih ili subjektiviziranih kriterijuma. U skladu sa nalazima našeg istraživanja, verujemo da će srednjoškolci i akademske ustanove koje ih kasnije upisuju trpeti zbog toga posebne posledice, stoga što se u najskorijoj budućnosti za učenike predviđa polaganje završnih, odnosno maturskih ispita, koji se ocenjuju na osnovu istovetnih kriterijuma za sve.

Prema uobičajenoj praksi, svi nastavnici, uključujući i one čije su ocene u korelaciji sa postignutim rezultatima, testove izrađuju ili biraju sami, što ostavlja više prostora za neujednačenost kriterijuma i odstupanje od osnovnih principa ocenjivanja. To ne znači da ne treba periodično primenjivati tzv. test nastavnika, već samo da će nastavnici veću objektivnost u ocenjivanju postići ako nastoje da načine provere jezičkih znanja i sposobnosti svojih učenika približe standardizovanim oblicima vrednovanja.

Naravno, ne može se reći da standardni testovi nemaju mana, niti da su idealni, što potvrđuje mnoštvo autora (Hughes 1996; Brown 2004; O’Sullivan 2011; Madsen 1993), ali svakako da daju veću sigurnost. Među manama možemo izdvojiti prilagođavanje nastave, pa shodno tome i učenja, samom testu, koji uzimaju maha i teško se iskorenjuju (Brown 2004: 112). Da bi se ostvarilo realnije ocenjivanje, smatramo da je po- 
trebno organizovati ozbiljniju obuku nastavnika, ali i osmisliti detaljnije kriterijume i parametre ocenjivanja jezičkih (posebno produktivnih) veština koji bi tokom kontinuiranog ocenjivanja upotpunili dostupne modele standardizovanih testova kakve nude međunarodni ispitni centri i izdavači ili one koji se mogu naći u priručnicima za nastavnike uz strane udžbeničke komplete. Ova dva koraka bila bi komplementarna, jer uprkos tome što se neke vrste testova (npr. na bazi višečlanog izbora) lakše ocenjuju, teže je oceniti produktivne veštine, odnosno svaku aktivnost koja zahteva kreativnu i relativno slobodnu upotrebu jezika.

Stoga smatramo da je neophodno ujednačiti sistem vrednovanja i ocenjivanja učeničkog postignuća u nastavi engleskog jezika kroz školski sistem, što se može postići redovnom primenom standardizovanih oblika provere znanja, uniformnih kriterijuma ocenjivanja i doslednim praćenjem već propisanih principa ocenjivanja. Ne treba posebno isticati kakve bi bile prednosti tako uspostavljenog sistema za same učenike, koji pokazuju visok stepen svesti i objektivnosti po pitanju svojih znanja i školskih ocena, pa i za obrazovni sistem u celini. Visokoobrazovne institucije bi tada takođe imale daleko realniju sliku o jezičkim kompetencijama kandidata koje upisuju i samim tim mogućnost da brže i efikasnije organizuju nastavni rad u pravcu podizanja njihovih jezičkih kompetencija ka višim nivoima postignuća.

Ovim radom želeli smo da ukažemo na neophodnost usklađivanja kriterijuma ocenjivanja na polju učenja ne samo engleskog jezika, već i drugih školskih predmeta, jer brojna iskustva iz prakse i iz ovog istraživanja govore o njihovoj neusaglašenosti. U nekom od narednih radova daćemo konkretan predlog posebnih parametara i kriterijuma ocenjivanja koji bi nastavnicima engleskog jezika u školama pomogli da ujednače sistem vrednovanja, a učenicima da dobiju ocene koje bi bile verni odraz njihovog truda i podstrek za dalje napredovanje. 


\section{Literatura:}

Angelo, T. A and Cross, K. P. (1988). Classroom Assessment Techniques. San Francisco: Jossey-Bass Publishers.

Brown, H. D. (2004). Language Assessment, Principles and Classroom Practices. White Plains, NY. Longman.

Fulcher, G. (2017). Criteria for Evaluating Language Quality. Language Testing and Assessment by Shohamy, Or and May [eds.]. Cham, Switzerland: Springer.

Gojkov, G. (2003). Dokimologija. Vršac: Viša škola za obrazovanje vaspitača.

Hughes, A. (1996). Testing for Language Teachers. Cambridge: Cambridge University Press.

Janković, N. (2017). Odnos ocene i postignuća u nastavi engleskog jezika. Nasleđe. Kragujevac: FILUM, god. XIV, br. 38, str. 39-53.

Janković, N. (2018). Evaluation, testing and assessment in English language teaching. Evaluation in contemporary education - theory and practice. Belgrade: Teacher Education Faculty. pp. 160-176.

Lazarević, Ž. Banđur, V. (2001). Metodika nastave prirode i društva. Jagodina - Beograd: Učiteljski fakultet u Jagodini, Učiteljski fakultet u Beogradu.

Madsen, H. (1993). Techniques in Testing. Oxford: Oxford University Press.

McKay, P. (2006). Assessing Young Language Learners. Cambridge Language Assessment Series. Cambridge: Cambridge University Press.

O'Sullivan, B. (2011). Language testing. In Simpson, J. (ed.) The Routledge Handbook of Applied Linguistics. London: Routledge.

Potkonjak, N, i Šimleša P. (1989). Pedagoška enciklopedija 1. Beograd: Zavod za udžbenike i nastavna sredstva.

Pravilnik o ocenjivanju učenika u srednjem obrazovanju $i$ vaspitanju (2015). Beograd: Sl. glasnik RS, br. 82/2015.

Pravilnik o opštim standardima postignuća za kraj opšteg srednjeg obrazovanja i srednjeg stručnog obrazovanja $i$ vaspitanja u delu opšteobrazovnih predmeta. (2013). Beograd: Sl. glasnik RS, br. 117/2013.

Tomović, A, Aralica, T, Rasulić, K. (2016). Mind the gap! Three years down the line from the entrance exam at the English department, Faculty of Philology, Belgrade. Belgrade English Language and Literature Studies, vol. VIII, Belgrade: Faculty of Philology, pp. 107-132.

Vilotijević, M. (2000). Didaktika III. Organizacija nastave. Beograd: Naučna knjiga i Učiteljski fakultet. 


\section{Nataša Janković, Nenad Tomović, Maja Aleksić \\ PRINCIPLES OF ASSESSMENT AND ASSESSMENT CRITERIA AS ESSENTIALS IN EDUCATIONAL EVALUATION}

Summary: A crucial aspect of quality evaluation in any educational context is the existence of predetermined principles of assessment and minutely elaborated assessment criteria, which is usually achieved through standardized tests. In order to meet the formally defined performance standards and the expected teaching outcomes in a foreign language classroom, teachers need to base the evaluation of their students' language knowledge and ability on the subject-specific criteria that will guarantee objective assessment. As a further step in the ongoing research, this comparative study presents the results of a survey conducted with 344 (377) students in three different educational institutions with the aim of investigating the correlation between the linguistic performance of novice university students and their high school grades in English, which allowed us to make further conclusions about the principles of evaluation and assessment criteria used in Serbian high schools. Based on the results of the questionnaire and the diagnostic test administered at the beginning of the academic year 2017/2018, the findings point to the conclusions that there are no uniform principles of assessment and that grading criteria vary considerably. This situation often results in discrepant levels of students' language knowledge and performance, which poses an obstacle in their further education. The authors will use the analysis to point to possible improvements in the assessment process and teaching practices.

Key words: principles of assessment, assessment criteria, evaluation, language knowledge, language skills, language ability. 